\title{
An attack called defence: the communication strategy of 'gender opponents' in Italy
}

\author{
Cristiana Ottaviano
}

University of Bergamo, cristiana.ottaviano@unibg.it ORCID 0000-0001-7128-4889

\begin{abstract}
'Gender Ideology' ('GI'), as an expression, appeared at the beginning of this century within documents of the Catholic Church with the aim of delegitimising what had been produced in the field of Gender Studies. That intent was strongly clarified, being coincident with the discussion in France about the law on equal marriage, during the protests of Manif pour Tous. Likewise, in Italy, oppositions to draft laws about homophobia and civil unions generated movements unified by the denouncing of 'GI'. This essay presents research conducted between 2014 and 2017 about online materials of some Italian associations that are positioned as 'GI opponents'. The content analysis underlines the use of a violent communication style that aims to create alarm and panic regarding presumed 'gender drifts' within social and educational contexts. This operation reveals the attempt to reaffirm an anthropological vision of sexuality based on the hierarchical-complementary relationship between male and female. The analysis highlights the risk of a sort of 'Silence Spiral', where - in the face of a noisy and violent minority - numerous and various voices disappear. These voices differentiate and invoke the urgency of a deeper debate about the concept of gender and its implications within educational, social and ecclesiastical contexts.
\end{abstract}

Keywords: Gender; Communication; Website; Catholicism; Social Inequality

\section{Birth of the enemy}

The term gender was first introduced in the area of scientific research with the expression 'sex gender system' (Rubin, 1975), which defines the social mechanism that confers characteristics and roles based on sexual differences between men and women. The category of gender was progressively adopted within American Academic research, and then in European research, and is used to analyse the social organisation of sexual diversity. That category, which allows the reading of social and cultural origins of the imbalance of the sexualised reality and recognises the difference between the sexes as the first terrain where power arises (Scott, 1988), is the base of the Gender Studies.

By the end of the past century, this concept assumed more and more centrality also within the international institutional debate and the gender perspective was taken on by the United Nations as a cornerstone to fight against inequalities. The Cairo Conference on Population and Development (1994) introduced a 'new paradigm' (McIntosh \& Finkle, 1995) essentially founded on women's right to control their reproductive functions and, above all, on the political need of granting those rights. The following year, the United Nations, during the IV World Conference about women in Beijing, integrated this perspective into its official documents.

In those forums, the Vatican's representatives formally defined their opposition to that concept - perceived as an interpretative category that introduces the denaturalisation of the sexual order - protecting, instead, an 'anthropological' vision of sexuality, based on the complementary relationship between male and female roles, particularly within the family. The 'Vatican's Nightmare Vision' (Case, 2011) leads to perceiving the use of the gender category as an attack on the fundamental values of life, family and social order. This attack is made even more dangerous by the adoption of that category by various institutional levels, what would now be characterised by a 'state feminism' (Stetson McBride \& Mazur, 1995).

The 'Lexicon. Ambiguous and debated terms about family, life and ethical matters', published in 2003 and edited by the Pontificio Consiglio per la Famiglia, repeatedly used the Gender Ideology lemma (referred to as GI from now on) to 
indicate a plan of denial of sexual difference, whose consequence would be the cancellation of human nature. Since then, the expression has been increasingly used in Catholic texts and conferences in different territorial contexts, until becoming a 'rallying cry' (Garbagnoli, 2016), particularly after 2011, when France introduced the topic of 'Becoming man or woman" in the High School programme and when it started the discussion about equal marriage.

From being a theme confined to the scientific debate, the question has increased its own social impact, mainly thanks to a massive and strategic use of online communication (see, amongst others, Meyrowitz, 1985; Giddens, 1990, 1991; Jenkins, 2006, Couldry, 2010; Hay \& Couldry, 2011): in fact, as we will see with reference to the Italian situation, the use of the Internet has allowed creating a social environment for sharing of information, actions and objectives that has reached a much wider audience; in some specific areas (such as Brescia and Verona), a real 'moral panic' (Garland, 2008) has ensued amongst parents and teachers.

The various definitions time to time ascribed to $G I$ by researchers and representatives of Catholic hierarchy clearly account for the aim of labelling, distorting and delegitimising what has been produced in the field of Gender Studies (Garbagnoli, 2014; see also Fassin, 2010; Fassin \& Margron, 2011; Fillod, 2014; Garbagnoli, 2016). Anatrella, Vatican consultant for related to family and health issues, defines $G I$ as a totalitarian ideology, more oppressive and destructive than Marxism (Conseil Pontifical pour la Famille, 2011); Cardinal Bagnasco, President of the Italian Episcopal Conference until May 2017, blames gender for the intention of demolishing the root of humanity itself in order to build a 'trans-human', where the human being appears as a nomad without destination or identity (Bagnasco, 2015).

Thus it starts a process of manipulation of the term gender that from a category, which could represent a fundamental interpretative key of social reality and is very useful in contrasting inequalities (Giaccardi, 2015), is transformed into a 'conceptual device' (Bernini, 2014) and used to counter the extension of rights and the not 'destined or determined' evolutionary vision of the relationships between sexes and between genders (Ottaviano \& Mentasti, 2015).

\section{Catholic activism against GI: research on Italian websites}

In Italy, that intent remained behind the scenes - at the public debate level - until opposition to the bills about homo/transphobia and civil unions (2013) was turned into a strong fight against the diffusion of GI into the social context and scholastic institutions by some associations. The alert grew with increasingly heated tones during the presentation in Parliament of a bill (nr. 1680/2014) proposing the introduction of gender education in schools.

Between 2014 and 2017, we investigated those nationally relevant associations that directly or indirectly refer to the Catholic environment by using qualitative research, particularly focused on websites. More specifically, in 2014, an explorative phase let us identify websites and materials to be monitored. In 2015, we set up a weekly monitoring, followed - until June 2017 - by a monthly monitoring, aiming at recording possible updates with a view to the spreading of the results of the research itself. The corpus of the research involved 11 websites (Alleanza Parentale, Associazione Non si Tocca la Famiglia, Associazione Voglio La Mamma, CitizenGo, Comitato Difendiamo i nostri Figli (CDNF), Federazione Italiana Scuole Parentali, Generazione Famiglia-La Manif pour Tous Italia (GF-LMPTI), Giuristi per la Vita $(\mathrm{GpV})$, No-Gender Italia, ProVita onlus, Sentinelle in Piedi). The homepages and the gender/school/education/press releases and documents' sections were analysed, according to the directions of the new media semiotics (see in particular Cosenza, 2014), in order to identify the deep concepts that regulate the structures of the texts (even in the case of 'hypertexts'). These concepts have been related to the intertext with which the text is intermingled (every reference more or less explicit to other texts of the cultural context in which it is inserted) and with the reference encyclopaedia, that is, in the sense attributed by Eco, the patrimony of beliefs and knowledge shared by contemporary society to that text (see Mentasti \& Ottaviano (2017) for a more detailed description of the empirical part).

The empirical research developed from the reconstruction of a territorial map and from the individualisation of the strategies aimed at the collecting and widening of audience consensus, with the analysis of contents, languages and images used to spread messages and online information. Therefore, the research verified the modalities used to build a wide net of consensus, to obtain validation into the ecclesiastic/religious environment and to make political alliances. Finally, it was important to broaden our vision towards those realities - lay and Catholic - that differentiate and distance themselves from the anti-gender movement, not sharing, in whole or in part, its approach, tones, certainties and implied values.

The whole of the research and comparison amongst the relevance of the different positions - in terms of social and media recognition - highlighted some asymmetric mechanisms, deriving, for example, from the role of noisy minorities or the articulation function of the media (Noelle-Nuemann, 1980).

The realities analysed, founded between 2012 and 2015, were born (at least those whose promoters/founders are identifiable $^{2}$ ) for the initiative of (and are directed by) people with a strong Catholic connotation; in some cases, on the

\footnotetext{
${ }^{1}$ The project embraces a perspective according to which human sexuality is not only limited to biological factors.

${ }^{2}$ The organisational structure of the analysed realities is difficult to know, and a more detailed research reveals the presence of a limited number
} 
homepages of the websites, there are explicit references to Christian values/foundations. For example, the Voglio La Mamma Association has been publishing an online magazine named La Croce (The Cross) and its objective is to open a club in each parish'; the Italian Federation of Parenting Schools states 'the centrality of God in school education'4; Alleanza Parentale declares: 'The goal of teachers? Pointing to heaven. The role of teachers [...] has to be characterised by vivid moral and religious concern', CitizenGo ${ }^{6}$ proposes a campaign of online petitions 'starting from a Christian vision of the human being and the social order'?

It is significant that the names chosen directly refer - in almost all cases - to two central themes that are recursive in objectives and actions: life and, for the realities born following the wave of the anti-gender protest, family. Therefore, the object of the ' $G I$ attack' is clearly identified, and 'the people" ${ }^{8}$ are called to respond.

Going into detail, on the website of LMPTI, ${ }^{9}$ there is a video titled 'Understanding Gender in less than three minutes', which starts off with these words: 'Are a girl and a boy equal? At a first sight, they are not. [...] However, for some, a girl and a boy are not different because they have a different body, but because parents, family, society, and education force them to be different. [...] And, as they are different, they are not equal. Yet, some see a problem here, the one of inequality between boys and girls, that later on becomes inequality between men and women. How do you solve it? Making girls and boys totally undifferentiated and, therefore, similar'. ${ }^{10}$

This is all evidence of a disingenuous confusion between the concepts of equality/inequality and difference/diversity (Besozzi, 1993, 2017²; Zanfrini, 2011), as if behind the battles for equality, rather than the refusal of using differences to justify discrimination and exclusion, the intention would be to make women and men undifferentiated. It is hypothesised a reductio ad unum (Marzano, 2015) flaunted as danger, whilst the threat that is really perceived, evidently, is the tipping over the edge of a social, cultural and institutional patriarchal system, threatened by the attempt of women to have, in their public life and even within the Church, equal recognition, the same rights and opportunities (see, e.g. Simonelli \& Ferrari, 2015).

Since 2014, anti-gender websites have multiplied the publication of documents, videos, open letters, articles and so on that define $G I$ as an attempt to subvert 'social relations on which every culture is based, first and foremost sexual diversity' (Generazione Famiglia, 2014, p. 22) and to undermine 'the right of every child to grow up and be educated with respect for and coherence with his/her own sexual identity, male or female'. ${ }^{11}$ Within the texts of posters and press releases dramatic and verbally strong terms such as 'attack on families', 'ethical deviation' and 'society deterioration' are used, and it is asked, 'will it still be possible to say "mum" and "dad"?' In numerous conferences, whose videos have been spread over the Internet, one of the most well-known representatives says GI states that 'one is male or female, man or woman, not based on how the person is biologically or sexually structured, but based on how one feels at the moment: one day male, the day after female, the day after that male again, after a week female again, or, how it happens to some transgender, every other month, one month male and the other female'. ${ }^{12}$

Thanks to the diffusion of various materials through different media, a particular shared 'knowledge' is spread: it aims at transmitting an univocal vision and interpretation of gender and of the risks that it implies, within a particular definition of values, meanings and visions of the world (Portier quoted in Saporiti, 2015). The diffusion strategy of that common knowledge is reinforced by mutual and continuous cross references or by the circulation of documents, petitions and news about activities supported by other anti-gender realities. Therefore, we witness mutual validations, reciprocal promotions, which certify the existence of a very tight net where those different realities are positioned.

The iconographic choice that inspires logos, posters and symbols of media campaigns, easily visible on the Internet, is clearly aimed at restoring a dichotomous division of the sexes, as the unique foundation and reason for the differences between men and women. Also, it clearly asserts the existence of only one model of family structure: the obsessively repeated use of the colour pink to define the feminine and blue for the masculine; the images of families always inevitably composed of a father, a mother and (at least) one boy and one girl, assaulted by the 'gender phantom'. These are iconographic choices that trace clear and unequivocal paths nor do they admit any deviation or shade.

It is, in my opinion, an implementation of the strategies of trivialisation and alarmism (and, in some cases, of hate speech $^{13}$ ) that might be read as functional to achieve at least three goals.

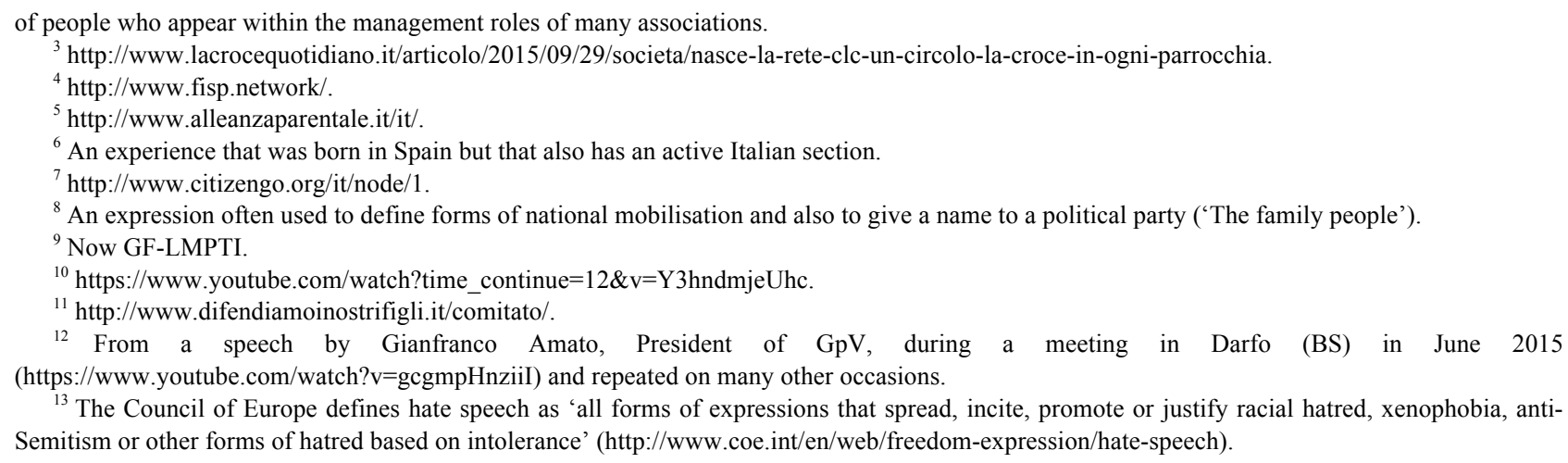


First and foremost, the trivialising simplification and obsessive recursion of messages make it possible to create impactful slogans, easy to transmit, which attribute to the term gender a load of 'destroying, obscurant, anti-social and anti-grassroots' threat (Generazione Famiglia, 2014, p. 22). This clear message has a strong emotional impact and is able to reach and potentially involve the general public. Therefore, significant consensus is being created, which is needed to be socially, culturally and politically incisive.

Second, the fight against GI becomes a keyword that unifies a set of battles and initiatives against the questioning of the sexual hierarchy, the extension of the rights of sexual minorities and the 'normalisation' of a reality where there are different forms and types of family relationships. All of this to propose a simple and absorbing interpretative framework (Van der Dussen, Paternotte \& Piette, 2016).

Third, the construction of hostile subjectivity, unified and homologated by GI, allows anti-gender movement to oppose a we that is equally homologated to a unique identity: the 'family people', whose mission is to defend the natural and anthropological order of humanity. These people stand up to protect children's rights (threatened by the GI colonisation of schools ${ }^{14}$ ) and are characterised by the conviction that the genuine Christian identity - evoked by the continuous call to the common religious matrix - could just entirely assume the anti-gender perspective, with all its implications and calls to the vision of roles, sexuality and family.

\section{Raising disgust in order to provoke fear and identity mobilisation: the strategies of a noisy minority}

The operation aimed at overturning and delegitimising the concept of gender may be defined as a sort of 'cultural jamming' (Lasn, 2000).

As we saw, the opposition to $G I$ is a unifying theme for the creation of a movement that radically objects to some cultural, social and political transformations in place. The goal is trying to reverse a trend, now also visible in Italy, which aims at extending the definition of citizenship rights. Looking at the changes in the roles of men and women and the family structures - which are increasingly characterised by a plurality of forms and systems of relation - there is a reaction that states a dichotomous vision, which is functional to affirm the hierarchical relationship between males and females (see, e.g. Miriano, 2011, 2016; Adinolfi, 2014), the heterosexual and the homosexual and so on and the uniqueness of the family form 'as a natural society founded on the marriage between a man and a woman, a social and anthropological place, appropriate for the birth, the growth and the care of offspring'. ${ }^{15}$

With this platform of post-materialistic goals (Inglehart, 1977), they try to increase the degree of consensus, using a participatory web also to gain the favour of the Catholic hierarchies, to solidify social relationships and to individualise political alliances. In the call launched in April 2015 on the homepage of La Croce, the bishops are asked to become promoters of a mobilisation of the Italian Church against the bills about homo/transphobia, civil unions and the 'introduction of gender education in schools and universities'. ${ }^{16}$ There has been also strong appreciation for the statements of Cardinal Bagnasco (2017).

Furthermore, lists of politicians have appeared on some websites as not to be voted because 'they have distinguished themselves for the diffusion of GI, ${ }^{17}$ or, on the opposite side, to be voted, because they were considered 'pro-family candidates'. ${ }^{18}$

The support of Catholic hierarchies and the setting of goals with some political representatives ${ }^{19}$ allow the antigender movement to acquire legitimacy and a sort of normalisation within the Italian debate, which, however, maintains itself very little inclined to give credibility to the movement (in many of its social, scientific, institutional and religious components). Think of the instances of the Italian Association of Psychology, ${ }^{20}$ of the Italian Society of Female Historians, ${ }^{21}$ of components of the Italian Association of Sociology (Gender Division) ${ }^{22}$ and of the Coordination of Italian Female Theologians (see Simonelli, 2015a, 2015b, 2016, 2017; Noceti, 2016; Tomassone, 2016; Torti 2013; Zorzi, 2017). Even the Ministry of Education intervened in the debate, clarifying that within the general rules of

\footnotetext{
${ }^{14}$ In 2015, the website of ProVita onlus published a dossier (also conveyed by other websites and periodically updated), titled 'Applied projects within Italian schools inspired by the gender theory and/or by homosexuality (https:/www.notizieprovita.it/wpcontent/uploads/2015/06/Speciale_Dossier_Progetti_Gender_Scuola_ProVita.pdf), which presents a hundred of projects and initiatives that took place in schools, as well as an index of 'gender and lgbt booklets'. The 'indicted' activities aim at dealing with bullying, gender stereotypes and violence and homo/transphobia.

${ }^{15} \mathrm{http}: / /$ www.difendiamoinostrifigli.it/comitato/.

${ }^{16} \mathrm{http}: / / \mathrm{www}$.lacrocequotidiano.it/articolo/2015/04/18/chiesa/appello-ai-vescovi-italiani.

${ }^{17} \mathrm{http}: / /$ www.no-gender.it/politici-da-non-votare/.

${ }^{18} \mathrm{http}$ //www.generazionefamiglia.it/candidati-per-la-famiglia-elezione-comunali-2017-manifesto-in-difesa-della-famiglia/.

${ }^{19}$ Think, for example, of the anti-gender window opened in 2016 by the Lombardy Region and also approved by the Regional Committee of Liguria, or of the Parliamentary question to 'know the measures that are intended to be adopted in order to contain that phenomenon of gay and gender propaganda which appears now to be spread in Italian schools' (presented by Roccella and others on March 17, 2015).

${ }^{20} \mathrm{http} / / /$ www.aipass.org/sites/default/files/AIP_position_statement_diffusione_studi_di_genere_12_marzo_2015.pdf.

${ }^{21} \mathrm{http}: / / \mathrm{www}$. societadellestoriche.it/images/sisnew2013/didattica/LetteraSIS_genere.pdf.

$22 \mathrm{http} / / /$ www.ais-sociologia.it/forum/ideologia-del-gender-o-studi-di-genere-comunicato-a-cura-di-alcun-componenti-della-sezione-ais-studi-digenere-4303/.
} 
schools, there is no reference to any ideology of any nature but only to the necessity to implement principles of equal opportunities, promoting education towards gender equality, prevention of gender violence and all other types of discrimination. $^{23}$

According to Bennato (2011), the sociological elements that characterise violent verbal behaviour are the adoption of values of intolerance, the feeling of belonging to a group and the perception of committing violence as a form of social legitimisation. These three elements clearly appear in the websites of 'gender opponents' analysed.

The anti-gender movement promotes the politics of disgust (Nussbaum, 2010), which encourages mobilisation against the perceived enemies (homosexuals and transgender and also women or men who claim a different role within society and Church), invoking an us identity, used as 'fictional means' (Remotti, 2010) to reach its goals.

The explicit assumption of the spokesmen of the movement is to represent a majority that has to come out of the shadow and replace the 'exit' option (keep to the sidelines) with the 'voice' one (make oneself be heard) (Hirschman, 1972). They invoke the identification with an in-group against an out-group (Sumner, 1906) considered to be a dangerous enemy; a minority, however, powerful; and a bringer of an instance, GI, that is a stranger to the Italian cultural tradition. They insist on this last aspect, also confirmed by the use of the term gender instead of the Italian genere, deploring the primary diffusion of GI by international institutions, such as the United Nations, the World Health Organisation, and the European Parliament (see, e.g. the "L'ideologia di genere" pamphlet by Generazione Famiglia (2014) and the section Press Releases on CDNF website).

Although it is important to take into account that in a pluralistic society, full of diversified voices, it is difficult to have an accordance of opinions, the media coverage of anti-gender positions contributes to the perception of their wide diffusion. It is precisely that coverage that may help develop a sort of 'Spiral of Silence' mechanism (Noelle-Neumann, 1980), which, especially within the Catholic environment, contributes to the perception of a predominance of those positions, also silencing part of those who would like to take a different stance. As Rita Torti states in an interview, not every position makes news, and not all voices make themselves heard at the same decibels. ${ }^{24}$

The impression is that, instead of a phenomenon that gives voice to an otherwise silent majority, we are in front of a noisy minority that feeds into the widespread trend of imagining conspiracies and of the difficulty of understanding a constantly changing social reality. In a context characterised by multiple minority positions, the major communicative force presumably relies on a greater ability to speak up.

The analysis of the contents of 'gender opponents' websites leads towards a resizing of widespread rhetoric that attributes an intrinsically libertarian spontaneity to the political subjectivity born from the Internet (Murru, 2016). It also highlights the problem of the use of new media as a factor that not necessarily reduces inequalities (Van Dijk, 2017). The issue of the democratic nature of the Internet, if reshaped as a question about the condition of truth and of the form of the knowledge that circulates there (Murru, Vittadini \& Colombo, 2012), declines itself with an extremely critical attitude towards the communication strategies - - here analysed - characterised by misleading simplifications, the activation of fears and the diffusion of social panic.

These distorted communication effects can lead to particularly dramatic outcomes above all on minors and, thus, the need for educational interventions to develop a critical approach also on the Web is confirmed, as the Media Education has been saying for decades (Rivoltella, 2001; Buckingham \& Willett, 2013).

\section{References}

Adinolfi, M. (2014). Voglio la mamma. Lecce: Youcanprint.

Bagnasco, A. (2015). Prolusione del Cardinale Presidente, Conferenza Episcopale Italiana, 23-25 marzo. Retrieved from http://banchedati.chiesacattolica.it/cci new/documenti cei/201503/233/Prolusione\%20Cardinale\%20Bagnasco.pdf

Bagnasco, A. (2017). Prolusione del Cardinale Presidente, Conferenza Episcopale Italiana, 20 marzo. Retrieved from http://educazione.chiesacattolica.it/bagnasco-i-genitori-si-coinvolgano-nelle-scuole/

Bennato, D. (2011). Sociologia dei media digitali. Roma-Bari: Laterza.

Bernini, L. (2014). [Uno spettro si aggira per l'Europa ...]. Sugli usi e gli abusi del concetto di 'gender', CAMBIO, (8), 81-90.

Besozzi, E. (1993). Elementi di sociologia dell'educazione. Roma: Carocci.

Besozzi, E. $\left(2017^{2}\right)$. Società, cultura, educazione. Roma: Carocci.

Buckingham, D. \& Willett R. (Eds.) (2013). Digital generations: Children, young people, and the new media. LondonNew York: Routledge.

Case, M. A. (2011). After Gender the Destruction of Man. The Vatican's Nightmare Vision of the 'Gender Agenda' for Law, PACE LAW REVIEW, 31(3), 802-817.

\footnotetext{
${ }^{23}$ Note nr. 1972/2015.

${ }^{24} \mathrm{http}: / /$ www.adista.it/articolo/55325.
} 
Conseil Pontifical pour la Famille (2011). Gender. La controverse. Paris: Téqui.

Cosenza, G. (2014). Introduzione alla semiotica dei nuovi Media. Roma-Bari: Laterza.

Couldry, N. (2010). Why Voice Matters: Culture and Politics After Neoliberalism. London: Sage.

Fassin, É. (2010). Les «forêts tropicales» du mariage hétérosexuel: Loi naturelle et loi de la nature dans la théologie actuelle du Vatican, REVUE D'ÉTIQUE ET DE THÉOLOGIE MORALE, (261), 201-222.

Fassin, É. \& Margron, V. (2011). Homme, femme, quelle différences?. Paris: Salvator.

Fillod, O. (2014). L'invention de la "théorie du genre": Le mariage blanc du Vatican et de la science, CONTEMPORARY FRENCH CIVILIZATION, 39(3), 321-333.

Garbagnoli, S. (2014). «L'ideologia del genere»: l'inarrestabile ascesa di un'invenzione retorica vaticana contro la denaturalizzazione dell'ordine sessuale, AG ABOUT GENDER, 3(6), 250-263.

Garbagnoli, S. (2016). Against the Heresy of Immanence: Vatican's 'Gender' as a New Rhetorical Device Against the Denaturalization of the Sexual Order, RELIGION \& GENDER, (2), 187-204.

Garland, D. (2008). On the concept of moral panic, CRIME, MEDIA, CULTURE, 4(1), 9-30.

Generazione Famiglia (2014). L'Ideologia di Genere. Retrieved from http://www.generazionefamiglia.it/wpcontent/uploads/2016/11/Generazione Famiglia Lideologia-di-genere.pdf

Giaccardi, C. (2015). Gender, oltre l'ideologia riappropriamoci del genere. Retrieved from https://www.avvenire.it/famiglia-e-vita/pagine/gender-non-solo-ideologia-riappropriamoci-del-genere-

Giddens, A. (1990). The Consequences of Modernity. Stanford: Stanford University Press.

Giddens, A. (1991). Modernity and Self-Identity: Self and Society in the Late Modern Age. Stanford: Stanford University Press.

Hay, J., \& Couldry, N. (2011). Rethinking Convergence/Culture, CULTURAL STUDIES, 25(4-5), 473-486.

Hirschman, A. O. (1972). Exit, Voice, and Loyalty: Responses to Decline in Firms, Organizations and States. Cambridge USA: Harvard University Press.

Inglehart, R. (1977). The Silent Revolution. Princeton: Princeton University Press.

Jenkins, H. (2006). Convergence Culture. Where Old and New Media Collide. New York: NYU Press.

Lasn, K. (2000). Culture Jam: How to Reverse America's Suicidal Consumer Binge - And Why We Must. New York: HarperCollins.

Marzano, M. (2015). Papà, mamma e gender. Torino: Utet.

McIntosh, C.A. \& Finkle, J.L. (1995). The Cairo Conference on Population and Development: A New Paradigm?, POPULATION AND DEVELOPMENT REVIEW, 21(2), 223-260.

Meyrowitz, J. (1985). No Sense of Place. The Impact of the Electronic Media on Social Behavior. Oxford: Oxford University Press.

Miriano, C. (2011). Sposati e sii sottomessa. Pratica estrema per donne senza paura. Firenze: Vallecchi.

Miriano, C. (2016). Quando eravamo femmine. Lo straordinario potere delle donne. Venezia: Sonzogno.

Murru, M.F. (2016). Il labirinto della cittadinanza. Le culture civiche in rete. Milano: Vita e Pensiero.

Murru, M. F., Vittadini, N., \& Colombo, F. (2012). Critica della Ragion Socievole. Le teorie davanti alla problematicità del web 2.0., COMUNICAZIONI SOCIALI, (2), 193-196.

Noelle-Neumann, E. (1980). Die Schweige-spirale. Öffentliche Meinung - unsere soziale Haut. Zürich-München: Piper.

Noceti, S. (2016). L'antropologia incompiuta, CREDERE OGGI, (213), 27-40.

Nussbaum, M. (2010). From Disgust to Humanity. Sexual Orientation \& Constitutional Law. Oxford: Oxford University Press.

Ottaviano, C. \& Mentasti, L. (2015). Oltre i destini. Attraversamenti del femminile e del maschile. Roma: Ediesse.

Ottaviano, C. \& Mentasti, L. (2017). Different Catholic Views on Gender Education in Italy: Identity closures or breaks to new challenges ahead?, AG ABOUT GENDER, 6(12), 160-189.

Pontificio Consiglio per la Famiglia (2003). Lexicon. Termini ambigui e discussi su famiglia, vita e questioni etiche. Milano: EDB.

Remotti, F. (2010). L'ossessione identitaria. Roma-Bari: Laterza.

Rivoltella, P.C. (2001). Media education. Modelli, esperienze, profilo disciplinare. Roma: Carocci.

Rubin, G. (1975). The traffic in women: Notes on the 'Political Economy' of Sex. In R. Reiter (Ed), Towards an anthropology of women (pp. 157-210). New York: Monthly Review Press.

Saporiti, M. (2015). The Catholic Metamorphosis in France: from Bioethics to Same-Sex Marriage. Interview with Philippe Portier, notizie di POLITEIA, XXXI(118), 41-51.

Scott, J. (1988). Gender and the politics of history. New York: Columbia University Press.

Simonelli, C. (2015a). Dire la differenza senza ideologie, IL REGNO, (1), 53-65.

Simonelli, C. (2015b). Teologia, differenza e gender: un dibattito aperto, STPAT, (62), 73-88.

Simonelli, C. (2016). Dio. Patrie. Famiglie. Le traiettorie plurali dell'amore. Segrate: Piemme.

Simonelli, C. (2017). Questione gender: un magistero poliedrico e prudente. In Facoltà Teologica dell'Italia Sett.-sez. di Torino (Ed.), Archivio Teologico Torinese (pp. 109-118). Bologna: Edizioni Dehoniane.

Simonelli, C. \& Ferrari, M. (Eds.) (2015). Una chiesa di donne e di uomini. Camaldoli: Edizioni Camaldoli.

Stetson McBride, D. \& Mazur, A. (Eds.) (1995). Comparative state feminism. London: Sage.

Sumner, W.G. (1906). Folkways. New York: Ginn.

Tomassone, L. (2016). A proposito di gender, AG ABOUT GENDER, 5(10), 250-260. 
Torti, R. (2013). Mamma, perché Dio è maschio? Educazione e differenza di genere. Cantalupa: Effatà. Van der Dussen, S., Paternotte, D. \& Piette, V. (2016). Habemus gender! Déconstruction d'une riposte religieuse. Bruxelles: Editions de l'Université de Bruxelles.

Van Dijk, J.A. (2017). Digital Divide: Impact of Access, The International Encyclopedia of Media Effects, 1-11.

Zanfrini, L. (Ed.) (2011). Sociologia delle differenze e delle disuguaglianze. Bologna: Zanichelli.

Zorzi, S. (2017). Il genere di Dio. La Chiesa e la teologia alla prova del gender. Molfetta: La Meridiana. 